\title{
A Genealogy of the Ridiculous: From 'Humours' to Humour
}

\section{Summary:}

We tend to take the phenomenon of humour for granted, seeing it for the most part as something innately and fundamentally human. However, we might go even further than this, and say that the phenomenon of humour is perceived as an essential part of what makes us human. In this respect, philosophers and theorists as wide apart as Aristotle and the French, feminist Julia Kristeva (1980; also see Goldberg, 1999a) have regarded a baby's ability to laugh as one of the earliest signs of the separation of 'self' from 'other', a reciprocal process deemed to be crucial to the formation of a separate identity.

However, although the general importance of humour might be agreed amongst researchers, what theoretical position one takes will have a profound effect on how one approaches and analyses humour. In much psychological research the focus tends to be on how humour works, i.e., syntax, semantic categories, sex differences, personality types, etc., and one finds a frustrating neglect of what is actually meant by the term 'humour' in terms of its history and emergence. Consequently, an important question tends to go unchallenged: Is humour some unproblematic innate human ability, or, a socially defined concept that has changed and mutated alongside our understanding of what it means to be person? In an attempt to grapple with this question, the following genealogical account is less concerned with fathoming out how humour works than with relating it to notions of human subjectivity, or how theories of humour have informed and reflected social constructs of what it means to be a 'subject'.

\section{Genealogy and Humour}

Tn adopting the Foucauldian notion of genealogy, this paper does not aspire to anything like the epic analyses of madness (The Birth of the Clinic), regulation (Discipline and Punish) and pleasure (The History of Sexuality) for which Foucault is renown (for an overview of Foucault's work see Rabinow, 1984, and Cousins and Hussain, 1984). Indeed, at first glance, using such a methodology in conjunction with such an apparently mundane and trivial topic as 'humour' might be considered singularly inappropriate. The impulse to do so was wrought out of the frustrations of trying to do psychological and psychoanalytic-based research on humour. After having trawled through numerous writings attempting to categorise and delineate the specific cognitive and linguistic dynamics peculiar to 'humour', as opposed to jokes and comedy, say, it became apparent that such distinctions were largely institutional artefacts. The attempt to pin down and delimit (order) 'humour' being symptomatic of psychology's own peculiar individualistic and paradigmatic mind-set. This concern to order or domesticate what was essentially a disor- 
derly phenomenon, or a diverse range of complex social relationships, manifested itself in a masculine absorbtion with the mechanics of jokes as a relatively accessible research topic. Meanwhile, humour's capacity to define relations of social conflict, power, and pleasure went neglected. Consequently, although I have appropriated the rather majestic term of genealogy my analyses are also informed by Barthes's (1972) observance, that ideologies do their work, not though grand narratives, but through de-politicising and naturalising those trivial, everyday concepts and artefacts we take for granted. Hence, such words as 'enigmatic' and 'elusive' commonly used to describe 'humour', point to the normative process by which the term has been interiorised and sanctified as an essential part of human 'nature'.

Thus, Barthes's Mythologies (1972) meets with Foucault's notion of genealogy as 'fiction' (Sheridan, 1989, p. 44), as a method not of establishing causality but of compromising the common-place, or, of offering alternative accounts for those seemingly self-evident, everyday concepts that barely seem to merit our notice. With this in mind, this paper adopts as its goal the Foucauldian deconstructionist one of égarement or 'bewilderment' (Sheridan, 1989, p. 46). That is, in the spirit of Foucault's genealogical tradition it invites you to 'lose your way' or 'to wander' from the obvious in favour of the alternative or unexpected path (ibid). This derailment of expectation, which Foucault (1971, reproduced in Rabinow, 1984 , p. 79) has analogised to the comic force of history, 'derisive and ironic, capable of undoing every infatuation', not only acts to 'fictionalise' or unmask psychology's own account of 'subjectivity' such that rather than searching for "that which was already there" [we dis-cover] ... not a timeless and essential secret, but the secret that they [such secrets] have no essence' (Foucault, 1971, citing Nietzsche, ibid, p. 78). Once 'humour' is re-politicised within the social conflicts and hierarchically classed formations of its various historical milieus we challenge its own well guarded secret. As such, we find - not essence - but that 'humour' is itself part of the same system of discourses of knowledge, or person theories, by which we come to 'know' what we are, and evaluate our behaviour. Thus, genealogy as a method to disordering truth is offered as a counter-discourse against psychological orthodoxy. As it aims to make non-sense (or comic fiction, see Goldberg, 1996) out of psychological common-sense it exposes how discourses of order and disorder have themselves become implicit to any definition of 'humour'. In this way, psychology itself is offered as an object for analysis and investigation as a prolific disseminator of ideological discourse (Ingleby, 1985; Rose, 1985). Hence, what starts out as a relatively simple investigation into 'humour' becomes not only a critique of knowledge but an analysis of power as it functions through 'humour' as a tool of social classification and regulation.

\section{The 'Subject' of Humour}

 $n$ his essay 'Nietzsche; Genealogy, History' (1971, reproduced in Rabinow, 1984, p. 94) Foucault likens genealogy to both 'masquerade' and 'the great carnival of time' where, as he says, the 'masks' of subjectivity are under constant transformation. According to Foucault, the task of the genealogist or deconstructionist is to sift through the debris of social history to expose the differing and ever changing 'faces', or discourses, of subjectivity. For the purposes of this paper this description of the historical process as resembling the procession of the 
carnival, or perhaps a series of theatrical 'performances' is especially apt, emphasising as it does the connection between "humour' (or the comical) and changing 'subjectivities'. Taking inspiration from Foucault, what follows is a historical account of the transformations of the humorous subject, or how theories about 'humour' have played an integral part in our conceptions of what it means to be human.

It is only when one starts to look at the history of 'humour' that one discovers just how ambiguous the concept is, and how it has changed its meaning over time and place. Indeed, if one looks back, one finds that the term 'humour' had a completely different meaning than the one it has today. In this respect it is perhaps fitting for the purposes of this paper that this story should begin with the original 'humours', a belief system which was to have major implications for future psychological theory.

The word 'humour' was originally a medicinal term meaning 'a secretion' or 'surplus' of the body (Stelmack and Stalikas, 1991 , p. 257). Aspects of the theory originated in Pythagoras (c. 582-507 BC) and Empedocles (c. 500-430 BC) and were later developed by Hippocrates (ca 460 BC). In its original meaning, to be in 'good humour', or 'good soul', simply meant to be in good health. As Koestler (1964, p. 48) reminds us, the ""humours"...were both liquids of the body and moods of the spirits'. It was in this respect, as Stelmack and Stalikas (1991, p. 259) note, that 'the palm', as a gauge of heat and moisture, was deemed, at the time, to be 'the best predictor of temperament'. It was not until Galen (AD 130-200) that the term started to acquire psychological connotations, and it is much later still that psychology, somewhat ironically, used this cosmological 'humoural subject' and the ancient sciences of astrology, palmistry and numerology as the foun- ding stones for an individualistic, internalised notion of 'personality' (Stelmack and Stalikas, 1991; and see Eysenck, 1964). This cosmological or chaotic heritage, as we will later see, still simmers, just awaiting its time of re-emergence, beneath the apparent scientism of psychological empiricism.

However, more to the present point of this story, we find that this medicinal legacy of the 'humours', and the concept of the ecological 'subject', was still the dominant form of knowledge in classical Grecian culture. Hence, somewhat disconcertingly, the humour historian finds that 'humour' in its original usage signifies something totally at variance with its modern 'internalised' psychologised notion of cognition or emotionality (the latter of which we encounter in Freud and other emotional release theories). The nearest thing to our present concept of 'humour' at that time tended to be referred to rather vaguely and ambiguously as 'comedy', the 'ludicrous', the 'ridiculous' or simply as 'laughter': But even here any expectations of encountering anything similar to a 'cognition' of humour are likely to be frustrated. As Paulos (1980) states, Grecian comedies were not so much 'jokes', as a polymorphous mixture of cosmological farce, phallic rites, parody, politics and knockabout obscenity.

This failure of expectation might arise from the fact that we have become so accustomed to thinking of the ancient Greeks as the originators of logical deduction that it is tempting to make the mistake of thinking that this reason derived from a similar form of self consciousness or 'subjectivity' to our own (Jaynes, 1976). However, as Pickering and Skinner (1990, p. 9) note, it is unlikely that the Greek philosophers had any notion of consciousness; preferring instead to regard the motive force for human action as emanating from an externalised source, and as part of 'a harmonious whole' (here, it is 
pertinent to note that the original meaning of psyche was breath or more generally lifeforce. See Jaynes, 1976). Consequently, although reason is said to have started with Aristotle, it is interesting to note that reason, or 'wit' in its original sense of 'knowledge', was the 'excellence' of the gods and 'not a human quality at all' (Schrempp, 1995, p. 227).

Since reason was so highly placed in the hierarchy of godlike virtues it is not surprising to learn that that which was considered an offence to reason among the ancient Greeks, demanded the highest form of ridicule. Socrates accordingly describes those deserving of laughter as those disobeying the Apollonian inscription to Know thyself (Plato, 1925, p. 333; my emphasis): an edict to know which has now been interiorised as self-regulation within psychology and psychoanalysis. However, since Greek culture was structured according to a strict hierarchy of ethical codes we find this aesthetic judgement changing in accordance with the status of the person committing the vice. So whereas Plato (1925, cited in Piddington, 1933) locates lack of reason 'in the powerful [as] hateful...in the weak it is merely ridiculous'. Hence, at a time when Tragedy represented the highest art form, laughter is reserved for wretches of a lower order. As Aristotle (1927, pp. 19-21) later observed, comedy is a representation of inferior people, not indeed in the full sense of the word bad, but the laughable is a species of the base or ugly'.

To appreciate the moral emphasis of Grecian comedy it should be remembered that Grecian society was based on a culture of classical and bodily aesthetics (Foucault, 1986; Piddington, 1933). The concept of $a c$ tion, as Pickering and Skinner indicate abo$v e$, is especially significant here, since the Grecian aesthetics of the 'self' and its pleasures was based on the concepts of active (or free) and passive bodies (with boys, women and slaves assigned to the passive role, not strictly through 'temperament' but more importantly through social position) (Foucault, 1976; 1985). As Barthes (1977, p. 104) tells us, '[i]n Aristotelian poetics, the notion of character is ... entirely subsidiary to the notion of action ... Later the character ... stopped being subordinate [and] ... embodied immediately psychological essences ... as can be seen in its purest form in the list of "character parts" in bourgeois theatre'. Consequently, it was only much later that 'pleasure', partly through the advent of psychoanalysis, was interiorised as an aspect of 'identity' (Foucault, 1976), a personification of 'essence' which has become the pivotal point for 'realist' theatre. We can observe this trend today in the format of the TV 'situation comedy' where the narrative is structured around a few 'gags', but where the real comedy derives from the stereotypicality and many psychological crises of its 'characters' (Woollacott, 1986).

The notion of 'humours' continued well into the Middle Ages. However, there is little evidence of its having acquired its present 'cognitive' and 'emotional' resonance; its use being, instead, still largely restricted to medicinal purposes (Bakhtin, 1968). Perhaps the best description of what 'humour' was like in the Middle Ages is provided in Bakhtin's book about the medieval writer Rabelais. As Bakhtin (1968, p. 28, footnote) states, there are many similarities between the Grecian comedy of Aristophanes and the medieval comedy depicted by Rabelais. Indeed, both writers can be seen to portray scenes of high farce where obscenity, bufoonery and debauchery act as satirical tools against the pomposity and hypocrisy of the political and religious elite of the times. In addition, both writers incorporate grotesque and classical imagery, within a literary genre that freely intermixes obscenity with clas- 
sical prose; a mixing of low and high cultures also seen in the work of Shakespeare, and that was to later draw scathing criticism from Enlightenment critics. As one such later critic, railing against this literary 'impurity', angrily complained, '[Rabelais's writing is, a] chimera; it has a lovely woman's face with the feet and tail of a serpent or some other more hideous animal. It is a monstrous jumble of delicate and ingenious observation and of filthy depravation' (cited in Bakhtin, 1968, p. 108).

\section{Enlightened Laughter: From Chaos to Order}

$\mathrm{H}$ owever, as Palmer (1994) and Thomas (1977) observe, right up to, and including the Middle Ages, this custom of mixing sacred and profane forms of entertainments was commonplace. It was only with the advent of the 'polite society' of the $1600 \mathrm{~s}$ and $1700 \mathrm{~s}$, and a classical redefinition of the arts and theatre into elitist and 'low' forms, that these more salubrious comedic 'farces' were barred from mainstream theatre. This hierarchical realignment of the arts (and the classes of people it was variously identified with - which were noticeably the lower classes) took place against a new appraisal of language. During the Middle Ages the use of rhetoric, 'punning', metaphor and analogy were not only an intrinsic ingredient of comedy but also part of medieval epistemology. Since, at that time, knowledge of the world was perceived to be locked into an integrated system of signs, which included language, the 'play' of puns, metaphors and analogies was a valid methodology for revealing the complex relationship of similarity and difference between signs (Palmer, 1994; also see Jaynes, 1976 , for a discussion of the important role of metaphor).
The period of the Enlightenment marked a break from this type of semiological deduction which had begun with Plato. Rationalism, in its demand for language transparency over opacity, dismissed the old 'punning' comedy style, and poetic logic, as 'low bred', unscientific and duplicitous, and summarily relegated it to 'popular culture'. As Thomas $(1977$, p. 80$)$ tells us, it is at this time that 'gravity' began to be taken for 'wisdom'. Thus, somewhat paradoxically the classical, 'profane', linguistic 'old' culture was redefined as a new culture - 'popular culture' - and associated 'with the speech of...uneducated "ordinary people" (Palmer, 1994, p. 141).

This growing bourgeois intolerance and distrust of anything, or any person, that could be associated with 'low' comedy, or what was now renamed 'popular culture', together with the splitting into 'low' and 'high' cultures, has to be evaluated against a background of other technological and scientific changes that were taking place during the 1700 s and 1800 s, and which were enforcing new regimes of social regulation. Science at that time was promising to reveal the natural laws of the universe. The clock as a symbol of industrialisation was restructuring the spheres of work and play, a displacement of popular culture that found its nemesis in the middle-class notion of $\mathrm{Ra}$ tional Recreation (Cunningham, 1980, p. 76) and its associated work-bound concept of 'leisure' (Goldberg, 1999b). As Stewart (1990) says, as Newtonian physics 'lay bare ... the motion of every particle in the universe, exactly and forever...Chaos gave way to the clockwork world'. This re-ordering was to have a wider moral and social significance for those excluded from this new world view as, 'order [was] equated with good and disorder with evil' (Stewart, 1990, p. 5).

The new hierarchically-sensitive morality of this period was reflected by humour 
commentators. As Thomas Wilson wrote in 1560, 'Laughter...is the fondness, the filthiness, the deformity and all such evil behaviour as we see in other(s)' (cited in Thomas, 1977, p. 78). Expanding on this moral theme, Hobbes (1588-1679) saw the function of 'laughter' as a corrective over 'folly', and consequently developed the 'degradation', or 'superiority' theory of humour, describing 'laughter' as a 'sudden glory arising from some sudden conception of some eminency in ourselves; by comparison with this infirmity of others', and where the wretch concerned is 'triumphed over' (Hobbes, 1914, cited in Piddington, 1933, p. 160).

What is so important about Hobbes is that his 'degradation theory' (somewhat aptly and revealing named) is an early example of an individualistic and psychological approach to 'humour' (Piddington, 1933). As Logan (reproduced in Pickering and Skinner, 1990) points out, it was about this time that the 'individual' as a concept was fully emerging, as agency was shifted from God to 'man' as the locus of his/her own destiny. However, although this engendered an increased awareness of 'individuality', this individual was not one 'that reflect[ed] on the fact, but a "self" still more orientated to the "outer" world than to its own "inner" character" (ibid, pp. 227-229).

Consequently, even though the Enlightenment heralded a period of increasing classification, this division and systemisation of knowledge was initially directed at external rather than internal phenomenon. Thus Hobbes's 'superiority' theory can be seen as an early example of what will later be known as the 'incongruity' or 'dissonance' theory of humour, except here the comparisons, or the 'conflicts', are derived from and limited to external, socially derived sources, as where, in the example above the 'difference' or 'incongruity' lies between diffe- rent classes of human bodies, such as the 'infirm' (the degraded) against the 'whole'.

As reason becomes the dominant form of 'subjectivity', however, we find a gradual shift from external to internal classifications of 'objects'. By the time we come to Beattie (1776) the 'clashes' of human bodies, has been replaced by the 'clashes', or 'incongruities', of ideas or cognitive categories. Consequently, whereas for Hobbes laughter arose through the comparison of one body with another, Beattie (1776) gives an example of 'incongruity' based on the 'dissonance' experienced between psychological or perceptual comparisons. Or, as he (ibid, pp. 583-705, my emphasis) says:

\footnotetext{
"from the view of two or more inconsistent, unsuitable, or incongruous parts or circumstances, considered as united in one complex object or assemblage, or as acquiring a sort of mutual relation from the peculiar manner in which the mind takes notice of them."
}

It is at this point that we at last start to see 'humour' taking on some of its contemporary, psychological meaning, as connoting an 'inner' awareness of the 'self', which is now located in this space called 'mind' (also see Goldberg, 1999b, for a more extensive analysis of the interiorisation of social 'space'). Thus, one is forced to the conclusion that modern-day definitions of humour, posed as a conflict of semantic, cognitive or emotive categories, are a direct result of the systemisation and internalisation of thought that occurred during the Enlightenment period, and it is this influence that continues to make 'incongruity' theories of humour still popular today in cognitive and 'humanist' based psychological research (see my discussion of Koestler below for a new rendition of this theory).

Alongside this new focus on 'cognition' or the mind, we also find Newtonian physics starting to impact on 'humour' theory as 
the discourse of 'energy' finds its metaphorical equivalent in the economies of the body (Bateson, 1972). Herbert Spencer (18201903) is important here in so far as he anticipates the Freudian notion of 'catharsis' through his explanation of 'laughter' as an 'overflow of surplus ... or redundant psychic "energy" that has no place to go' (Paulos 1980 , p. 4, citing Spencer, 1911). Moreover, (anticipating Darwin) he combines this approach with his own version of social Darwinism to give a bizarre evolutionary twist to 'incongruity theory', insisting on a 'descending [and implicitly hierarchical] order of incongruity' (Piddington, 1933, p. 28, citing Spencer, 1911). Additionally, and perhaps more revealing still, he identifies this paradox as stemming from the fact that 'some [psychical] states of consciousness' are 'inferior in mass to others' (ibid., my emphasis).

By the time we get to Sigmund Freud, the importance of his contribution, as Forrester (1980) indicates, lies not so much in its content (although this is significant) as in the way his work on humour integrates many of the representational systems of thought mentioned above (i.e., evolutionary theory, biology, rationalism, 'superiority', 'incongruity' and 'surplus energy') into one model of 'personality'. Not only this, but Freud partly reflected, and was instrumental to a wider scientific and bourgeois interest in the internal mechanisms of personality. As Logan (reproduced in Pickering and Skinner, 1990 , p. 230) says, in the 1800 s there was 'an historic shift from "How do I (subject) reason about and observe the world?", to "How does the world make me (object) feel?", and "what has experience made of me?"'. Freud's therapeutic methods not only answered this call to find ones' 'inner' self, an edict 'to confess' which was also being answered and promoted by the new discipline of psychology, but his model also served to represent a 'picture' of the social world, in microcosm, embodying many of the social and classed conflicts that were also of concern to his bourgeois clientele.

Correspondingly, in Freud's (1905) book on jokes, we find not only a phylogenetic and developmental account of 'witz' (ranging from a lascivious and grossly sensual, plebeian, id-driven 'smut' to the intellectual and super-ego civilities of 'humour'), but also a social analogy of the many conflicts and inhibitions that were implicated in the transition to a more 'civil' society and which was placing the middle classes (like the ego) as the mediator between an increasingly interventionist 'repressive' state, and the disorderly force of a lower class rabble (see Goldberg, 1999b). This social conflict was later to be mirrored in Freud's (1923) structure of the psyche. Speaking of this relationship, Freud (ibid, p. 397) argues that '[w] see this...ego as a poor creature owing service to three masters and consequently menaced by three dangers: from the external world, from the libido of the id, and from the severity of the super-ego'. Moreover, in his description of the joking process as travelling from 'Bewilderment [chaos] to Enlightenment [order]' (1905, p. 45), Freud not only metaphorised the hypothetical-deductive method so beloved of psychology and the social sciences, but also moved from diverse and inconclusive forms of pleasure to the possibilities of solution.

\section{The Machine, the Comic and the Cosmos}

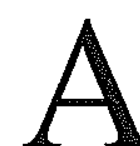

$\mathrm{t}$ about the same time as Freud, Bergson (1914) was also articulating, and incorporating his social concerns within another theory of 'humour'. Bergson's contrast between man and machine as the essence of humour has no di- 
stinguishing merits until one locates it in the increasing industrialised historical milieu of its creation. In this context, Bergson's (1859-1941) theory of 'vitalism', and his (ibid, p. 58) description of the ludicrous as any situation where 'a person gives us the impression of being a thing' takes on new significance. He not only articulates a widespread fear of the 'new' machines (viz. the film Metropolis, 1926), but his specific fear that the mechanisation of labour was transforming workers into 'clockwork' automatons, not only in terms of bodily repetition, but also psychical conformity. In making these observations, he might be viewed as offering an account which parallels a Marxist focus on objectification, exploitation and alienation.

This mechanistic view of 'subjectivity' found its apotheosis in the functionalist discourses surrounding behaviourism, operant conditioning, social conformity and social utility. Consequently, it is no coincidence that during the 1920s and 1930s we find humour theorists looking more and more at the social and group functions of humour. Here, the discourses of 'utility' and regulation portray 'humour' as an instrument of social control, and as a method by which to extol conformity by the process of public ridicule, whereby society achieves cohesion through in-group banter and out-group stereotyping (see Dupréel, 1928). In the process the dynamics of power are individualised and depoliticised under the euphemism of 'social influence'.

Once again, however, this focus on 'utility' needs to be appraised within the context of other theoretical influences at work. The interest in 'utility', social 'functionalism' and conformity not only marked a quest for scientific status, and a rejection of the old philosophical 'subject', but, in emphasising 'adaptation', it reflected the popularisation of social Darwinism, which was then often mixed in with a Newtonian/Freudian-informed conception of 'surplus energy'. We find an example of the integration of these discourses in Piddington's (1933, p. 64) book The Psychology of Laughter: A Study in Social Adaptation where he freely intermixes anthropology and social Darwinism as, for instance, when we are told, that in its most elementary 'stimulus situation' laughter is best observed in 'animals', 'persons of low-grade intelligence, and children'. Here he combines a discourse of 'humour' as a method of social control, with one of social 'release'. Further on, we find cognitive psychology completing the 'man/machine' analogy in the form of information processing, artificial intelligence and cybernetics.

More recent psychologically-orientated research has combined this cognitivism with a humanist approach to provide a modern 'Iinguistic' twist to 'incongruity' theory. In Arthur Koestler's (1964) book The Act of Creation he gives us an account of the generative paradoxical functions of humour. Here, as befitted the times and the status of scientific thought, we are often referred to psychological 'models' and the clashing of incongruities - a sort of big bang theory of humour - where the 'act of creation' takes place, and the 'discovery' emerges alongside the scientific man out of the clashing of 'universes of discourse' (Koestler, 1964, p. 40).

\section{From Order to Chaos and Back Again: Or Coming out to Play in a Postmodern World}

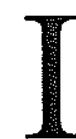
n more recent times, the Newtonian metaphysics of order has been eclipsed by a more 'chaotic' theory of subjectivity and, through its association with the 'self' the definition of 'humour' is itself under- 
going a transformation. (For a discussion of whether this is a postmodern 'shift' or merely a logical extension of modernity, see Jameson 1991; Heller 1996; Parker, in press). If 'humour', in its celebration of reason and the cerebral, is a quintessential modernist concept, then, in the postmodern critique of modernity we are witness to a re-appropriation of the more polymorphous and infantile indeterminacies of play. While humour, as Freud identified, denoted adult restraint, sublimation, and mastery of language, play is evocative of a more child-like status, where pleasure is diffused, action based and bound to the sensuous pleasures of the body. In literary and academic circles the transition to the chaotic politics of play and the espousal of a new 'chaotic' or decentred 'subject' has to be situated within the revolution wrought by the 'uncertainties' of quantum physics: an ascendancy of playfulness (or disorder) over order epitomised by such hedonistic terms as 'jouissance' (Lacan, 1977), 'pleasure' (Barthes, 1977; Foucault, 1976; 1985), 'play' and 'différance', (Derrida, 1978; 1982), and Donna Haraway's (1991) vision of a cyber-. netically 'ironic' 'cyborg'.

As a symptom of this sea-change we find that irony is quickly usurping humour as the preferred mode of postmodern critique. As Eagleton (1988), echoing Sloterdijk (1984), notes, irony is subversive without being political and, like its close relation, parody, is symbolic of both the 'jaded' resignation and deep cynicism pervading the postmodern. Consequently, whereas Freud (1905) described humour as 'tendentious' (purposeful), play in its disdain of purpose has only anarchical (or disorderly) ambitions. Similarly, whereas 'humour' as a rationalistic term incorporated the ideology of progress by logic, illustrated by Freud's description of the joke dynamic as one from 'bewilderment to enlightenment', play and its compa- triots, parody and irony, recognise neither enlightenment nor solution but are commensurate with a social mood which increasingly sees truth and knowledge as contingent. However, although the discourse of 'chaos' has, for the time being at least, taken the place of the old order its role is primarily supportive. As chaos theory reclaims 'free will', or freedom over determinism, contextuality over structure, transition over stability, it partakes in the constitution of the transient, 'flexible', pleasure-oriented 'subject' required of global capitalism. Thus, rather than 'cognitive dissonance' or 'incongruity' theories of humour, such terms are increasingly being replaced by the more superficially grounded concept of 'paradox'. The term 'paradox' effectively serves to de-politicise, neutralise and displace what was once known as ideological conflict in favour of an approach whose most critical aim is to 'play with' or 'contrast' texts.

Since order always has a tendency to reincorporate chaos, and as institutionalised order and regulation re-asserts its hegemony, we find 'chaos', in the form of quantum ideas, creeping surreptitiously into psychological discourse (cf. Abraham and Gilgen, 1995, Chaos Theory in Psychology; and Robertson and Combs, 1995, Chaos Theory in Psychology and the Life Sciences). The history of the social sciences has ever been one of parasitic dependence on the representational systems of the natural sciences, and in psychology we find chaos theory being used to promote both regulatory and humanist reinterpretations of human behaviour. At one extreme of this movement, chaos is championed as a valediction of the market ideals of 'freedom', 'free choice' and self determination (Turner, 1997, p. xiv), where understanding and regulating interactive systems rather than predicting behaviour becomes the scientific agenda; an agenda which implicitly, as the following quote de- 
monstrates, seeks to subsume chaos to order. "“[U]npredictable", as Turner (1997, p. xiv, emphasis added) points out, "does not necessarily mean "unintelligible," or inaccessible to knowledge and understanding...freedom now becomes a rich and useful concept, reciprocally defined by, and suggesting ways to understand, non-linear complexity'.

Meanwhile, at the other end of this spectrum, the appeals to freedom and creativity viz a viz 'play' (as it connotes freedom from structure and the play of divergent forces) acquire both nostalgic and spiritual connotations. Such post-structuralist terms as 'flows', dialectics, dynamics, mutuality, dialogue, community and connectedness are promoted alongside the more mystically informed Jungian (1959) ideas of 'synchronisation', sacred geometry and 'archetypes' as the way to reclaim a more humanist, spiritual, joyous and globalised psychology. Detailing the possibilities of 'chaos' for the psychological project, Peat (1995, p. 361) finds spiritual succour in a comic and cosmological legacy,

\footnotetext{
"That great summing up of the medieval world, Dante's Divine Comedy, drew upon a sacred geometry in which everything and everyone had their place.....By making a journey through a highly structured landscape, the traveller moves towards harmony and balance. Dante's landscape is at one and the same time theological, cosmological, social, and individual; it is an image of the integration of the psyche and of the dynamics of the solar system, for both individual and cosmos are subject to that same love that moves the sun and star."
}

Although the above quote gives some indication, it is nevertheless difficult within the limited confines of this article to convey the full measure of the spiritual and humanist desires being invested in the notion of 'chaos'. These yearnings not only import to 'chaos' the promise of an answer of truly cosmic and psychological proportions, the mystery of creation from the whirlpool to the rumblings of neurotic impulses' (Ainslie, 1995, p. 309) but to the unifying capacity of 'chaos' to harmonise the diverse strands within psychology's own history and discipline (Abraham and Gilgen, 1995).

This celebration of a 'nonlinear revolution and the ecological transformation' (Goerner, 1995, p. 37) parodies a more momentous quest for universal meaning also taking place in the natural sciences as it searches for its own Newton/Einstein type of 'Grand Unified Theory' (Stewart, 1990, p. 9). Although, in psychology, this celebration of chaos is discoursed as progressive and as furthering the course of psychological science, de facto, the knowledge it craves is of an ancient or 'pre-modern' kind (Young, 1995, p. 218). Thus, psychology turns full circle and, as always implied, returns to its 'ancient 'universal heritage' and 'archetypal roots' where it 'once again...[reembraces] the idea of chaos after its long absence' (Bütz, Duran and Tong, 1995, p. 328). .

\section{Conclusion}

$\mathrm{T}$

This paper has attempted to demonstrate that no concept is so mundane or 'natural' as to be immune to social analysis. This is especially important in such concepts as 'humour' which have acquired almost transcendental qualities in their purported association with human essence. In charting the history (or disorderly path) of humour in its various guises, from 'humours' to temperament, to psyche and beyond, this paper has tried to show how changes in scientific knowledge not only has the power to redefine and re(order) human behaviour but to relocate it in spatial terms, such that, what was of an external and social origin becomes interiorised. Just 
as Foucault (1976; 1985) documented the process by which 'pleasure' (in its very widest sense) became subsumed within identity, humour as an enlightenment model has suffered a similar fate of privatisation. While humour or witz, served to encapsulate all those qualities, such as, knowledge, the intellect, sublimation, civility, admired by Reason, play, in contrast, is cast in the role of modernity's somewhat petulant and infant nemesis connoting, as it does, rebellion, deconstruction and an infantile sensuality. Yet, hence, we become seduced into believing that the social sciences in their new found poetics and spiritual playfulness are set to forget themselves it is as well to note, as Price (1997, p. 14) admits, that 'postmodernists and theorists of chaos and complexity are undertaking entirely different projects. [whilst] Postmodernists want to de-construct science; complexity theories want to reconstruct it'.

\section{References}

Abraham, F. D. and Gilgen, A. R. (eds) (1995). Chaos Theory in Psychology. London: Greenwood Press.

Ainslie, P. (1995). Chaos, psychology, and spirituality. In Robertson, R. and Combs, A. (eds). Chaos Theory in Psychology and the Life Sciences. NJ: Lawrence Erlbaum.

Aristotle (1927). The Poetics. Trans. by Hamilton Fyfe. London: Heinemann.

Bakhtin, M. (1968/1984). Rabelais and His World. Bloomington: Indiana University Press.

Barthes, R. (1972). Mythologies. London: Jonathan Cape.

Barthes, R. (1977). Image - Music - Text. Trans. by Stephen Heath. London: Fontana Press.

Bateson, G. (1972). Steps to an Ecology of Mind: Collected Essays in Anthropology, Psychiatry, Evolution and Epistemology. London: Jason Aronson.
Beattie, J. (1776). 'An Essay on Laughter, and Ludicrous Composition'. Essays, Edinburgh: William Creech.

Bergson, H. (1914), Laughter: An Essay on the Meaning of the Comic. Trans. by loudesley Brereton and Fred Rothwell. NY: The Mamillan Company.

Bütz, M. R., Duran, E. and Tong, B. R. (1995). Cross-cultural chaos. In Robertson, $\mathrm{R}$, and Combs, A. (eds). Chaos Theory in Psychology and the Life Sciences. NJ: Lawrence Erlbaum, pp. 319-329.

Cousins, M. and Hussain, A. (1984), Michel Foucault. London: Macmillan.

Cunningham, H. (1980). Leisure in the Industrial Revolution. London: Croom Helm.

Derrida, J. (1978). Writing and Difference. Trans. by Alan Bass. London: Routledge.

Derrida, J. (1982). Margins of Philosophy. Trans. by Alan Bass. Brighton: Harvester Press.

Dupréel, E. (1928). Le problème sociologique du rire. Revue Philosophique, 106, 213-260.

Eagleton, T. (1988). Literary Theory: An Introduction. Oxford: Basil Blackwell.

Eysenck, H. J. (1964). Principles and methods of personality description, classification and diagnosis. British Journal of Psychology, 55, 284-294.

Forrester, J. (1980). Michel Foucault and history of psychoanalysis. History of Science, 18 , 286-302.

Foucault, M. (1971). Nietzsche, Genealogy, History. Essay originally published in Hommage à Jean Hyppolite. Paris: Presses Universitaires de France, pp. 145-172. Reproduced in Rabinow, P. (1984) (ed.). The Foucault Reader. London: Penguin, pp. 76100.

Foucault, M. (1976/1978). The History of Sexuality, Volume 1: An Introduction. Harmsworth: Penguin.

Foucault, M. (1985). The History of Sexuality, Volume 2: The Uses of Pleasure. Harmondsworth: Penguin.

Foucault, M. (1986) The History of Sexuality, Volume 3: The Care of the Self. Harmondsworth: Penguin. 
Freud, S. (1905/1976). Jokes and Their Relation to the Unconscious. London: Pelican.

Freud, S. (1923). The Ego and the Id. Pelican Freud Library 11, trans. J. Strachey and A. Strachey, Harmondsworth: Penguin.

Goerner, S. J. (1995). Chaos and deep ecology. In Abraham, F. D. and Gilgen, A. R., Chaos Theory in Psychology. London: Greenwood Press. pp. 3-18

Goldberg, B. (1996). In a bad humour ... with psychology. In Burman, E., Alldred, P., Bewley, C., Goldberg, B., Heenan, C., Marks, D., Marshall, J., Taylor, K., Ullah, R., and Warner, S. Challenging Women: Psychology's Exclusions, Feminist Possibilities (pp. 54-70). Buckingham/Philadelphia: Open University Press.

Goldberg, B. (1999a). Specular comedy: double acts. Psychoanalytic Studies, 1(1), 15-26.

Goldberg, B. (1999b). Spatial transitions: contesting the limits of social and psychic space. Psychoanalysis and Contemporary Thought, 22(3), 315-341.

Haraway, D. (1991). A cyborg manifesto: science, technology, and socialist feminism in the late twentieth century. In Simians, Cyborgs and Women. London. Free Association Books.

Heller, R. (1996). The tale of the universe for others. In Lykke, N. and Braidotti, R. (eds) Between Monsters, Goddesses and Cyborgs: Feminist Confrontations with Science, Medicine and Cyberspace. London: Zed Books Ltd.

Hobbes, T. (1914). The Leviathan. Intr. by A. D. Lindsay. London: Dent.

Ingleby, D. (1985). Professionals as socializers: the 'psycomplex'. Research in Law, Deviance and Social Control, 7, 79-109.

Jameson, F. (1991). Postmodernism Or, the Cultural Logic of Late Capitalism. London: Verso.

Jaynes, J. (1976). The Origin of Consciousness in the Breakdown of the Bicameral Mind. London: Allen Lane.

Jung, C. G. (1959). The Archetypes and the Collective Unconscious. Trans. by R. F. C. Hull. London: Routledge \& Kegan Paul.
Koestler, A. (1964/1976). The Act of Creation. London: Hutchinson \& Co.

Kristeva, J. (1980). Desire in Language. Oxford: Basil Blackwell.

Lacan, J. (1977). Ecrits. London: Routledge.

Metropolis (1926). Dir. Fritz Lang.

Palmer, J. (1994). Taking Humour Seriously. London: Routledge.

Parker, I. (in press). Against postmodernism: psychology in cultural context. Theory and Psychology.

Peat, F. D. (1995). Chaos: the geometrization of thought. In Robertson, R. and Combs, A. (eds). Chaos Theory in Psychology and the Life Sciences. NJ: Lawrence Erlbaum, pp. 359- 372.

Paulos, J. A. (1980). Mathematics and Humour. London: The University of Chicago Press.

Pickering, J. and Skinner, M. (eds) (1990). From Sentience to Symbols: Readings on Consciousness. Hemel Hempstead: Harvester Wheatsheaf.

Piddington, R. (1933). The Psychology of Laughter: A Study in Social Adaptation. London: Figurehead.

Plato (1925). Philebus. (Ed.) by Harold, N. Fowler. London: Heinemann.

Price, B. (1997). The myth of postmodern science. In Eve, R. A., Horshall, S. and Lee, M. E., Chaos, Complexity, and Sociology: Myths, Models, and Theories. London: Sage. pp. 3-14.

Rabinow, P. (1984) (ed.). The Foucault Reader: An Introduction to Foucault's Thought. London: Penguin.

Robertson, R. and Combs, A. (eds) (1995). Chaos Theory in Psychology and the Life Sciences. NJ: Lawrence Erlbaum.

Rose, N. (1985). The Psychological Complex: Psychology, Politics and Society in England, 1869-1939. London: Routledge \& Kegan Paul.

Schrempp, G. (1995). Our funny universe: on Aristotle's metaphysics. Oring's theory of humor, and other appropriate incongruities. Humor-International Journal of Humor Research, 8(3), 219-228. 
Sheridan, A. (1989). The death of the author. In Appignanesi, L. (ed.). Ideas from France: The Legacy of French Theory: ICA Documents. London: Free Association Books, pp. 41-48.

Sloterdijk, P. (1984). Cynicism: the twilight of false consciousness. New German Critique, 33: 190-206.

Spencer, H. (1911). On the Physiology of Laughter: Essays on Education and Kindred Subjects. London: Dent.

Stelmack, R. M. and Stalikas, A. (1991). Galen and the humour theory of temperament. Journal of Individual Differences, 12(3), 255-263.

Stewart, I. (1990). Does God Play Dice: The New Mathematics of Chaos. Harmondsworth: Penguin Books.

Thomas, K. (1977). The place of laughter in Tudor and Stuart England, Times Literary Supplement. 21 January, 77-81.
Turner, F. (1997). Chaos and social science. In Eve, R. A., Horshall, S. and Lee, M. E., Chaos, Complexity, and Sociology: Myths, Models, and Theories. London: Sage. pp. xixxvii

Woollacott, J. (1986), Fictions and ideologies. The case of situation comedy. In Bennett, $\mathrm{E}$., Mercer, C. and Woollacott, J. (eds) Popular Culture and Social Relations. Milton Keynes: Open University Press, pp. 198-218.

Young, T. R. (1995). Chaos theory and social dynamics: foundations of postmodern social science. In Robertson, R. and Combs, A. (eds). Chaos Theory in Psychology and the Life Sciences. NJ: Lawrence Erlbaum, pp. 217-233. 


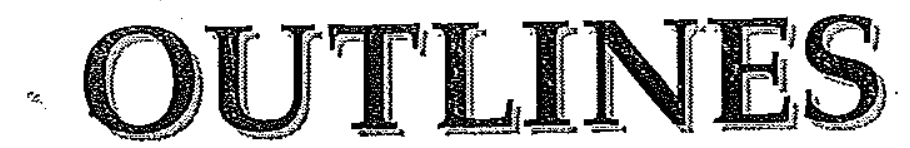

\section{Critical Social Studies}

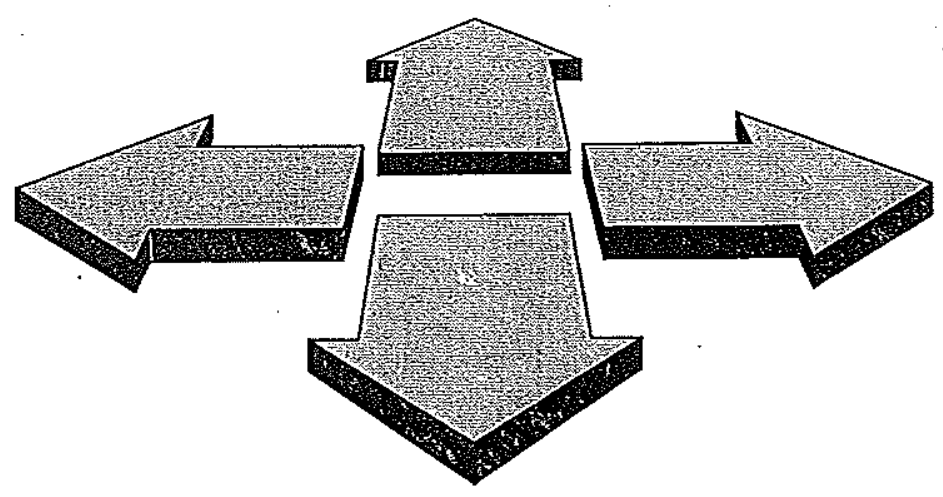

Editorial 1

Personal Trajectories of Participation across

5 Ole Dreier

Contexts of Social Practice

Imagine the World you Want to Live in:

33 Ritva Engeström

A Study on Developmental Change in Doctor-

Patient Interaction

The Emergence and Role of Client Perspectives

51 Hysse Birgitte Forchhammer

in and on Cancer Treatment

A Genealogy of the Ridiculous:

59 Brenda Goldberg

From 'Humours' to Humour

The Project "Analysis of Psychological Practice"

73 Renke Fahl \& Morus Markard

or: An Attempt at Connecting Psychology

Critique and Practice Research

\section{Dansk psykologisk Forlag}




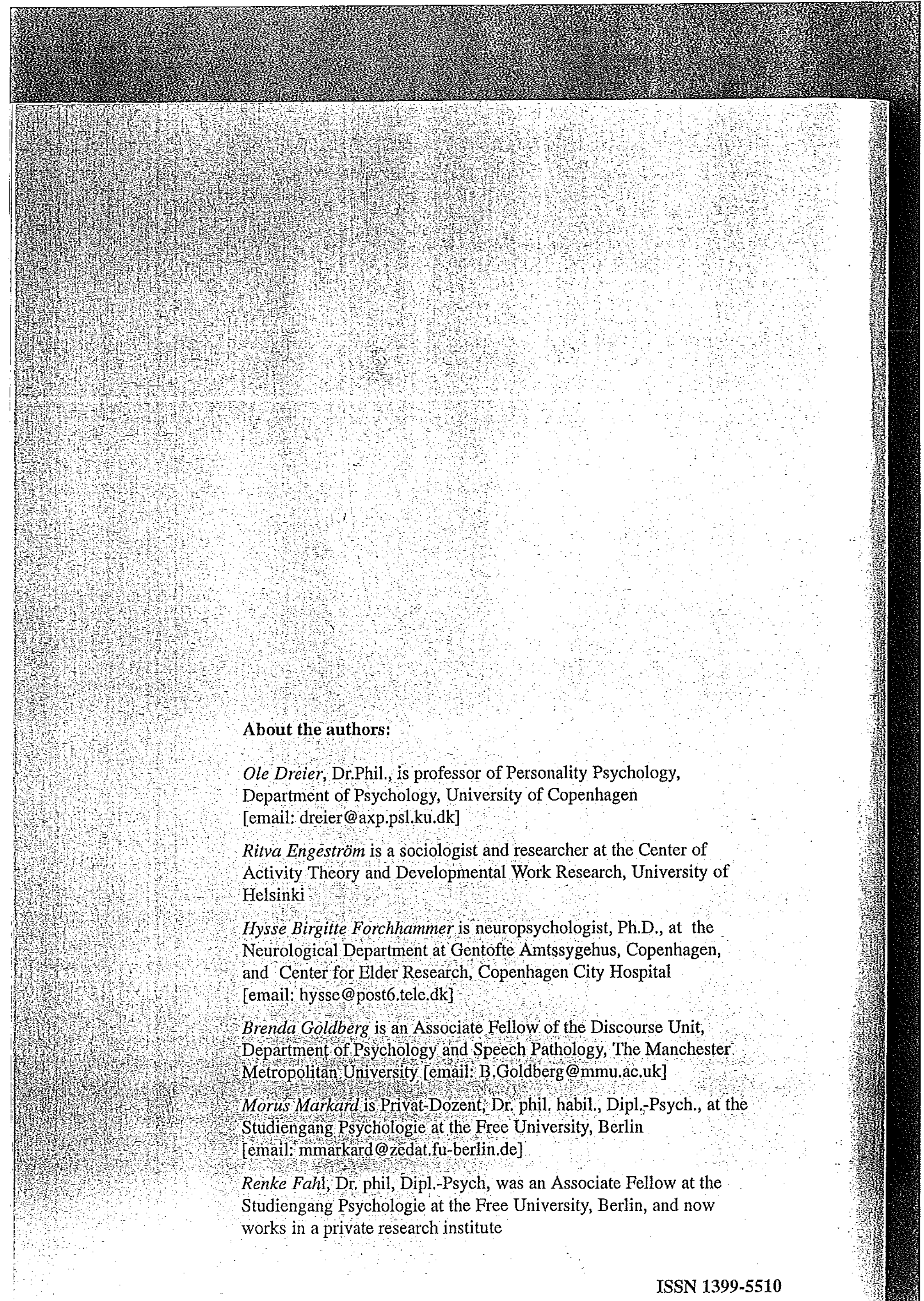

